\title{
PENERAPAN PENDEKATAN QUANTUM (QUANTUM TEACHING AND LEARNING) MATA PELAJARAN DASAR-DASAR AKUNTANSI UNTUK MENINGKATKAN PRESTASI BELAJAR SISWA KELAS X SMK
}

\author{
ELLIS SUSMAWATI \\ Email: ellisramadhani78@gmail.com \\ SMPN I Semen Kabupaten Kediri
}

\begin{abstract}
Abstrak
Tujuan penelitian ini adalah menerapkan metode pembelajaran quantum teaching untuk meningkatkan motivasi dan aktifitas siswa, teknik analisis data statistik deskriptif: prosentase dan rata-rata. Hasil penelitian siklus pertama motivasi dan aktifitas peserta didik dengan kategori $60 \%$ kurang dan $40 \%$ cukup. Test hasil belajar nilai $40 \%$ kurang dan $60 \%$ cukup. Hal ini disebabkan peserta didik belum terbiasa dengan pembelajaran model quantum teaching. Siklus ke dua pelaksanaan pembelajaran dengan model quantum teaching ditambah dengan metode ceramah dimana guru masih menjelaskan hal-hal yang penting menghasilkan motivasi dan aktifitas siswa $40 \%$ berkategori cukup dan $60 \%$ berkategori baik. Sedang test hasil belajar $40 \%$ siswa mempunyai nilai cukup dan $60 \%$ siswa mempunyai nilai baik. Siklus ke tiga pembelajaran model quantum teaching siklus ketiga $40 \%$ siswa mempunyai motivasi dan aktifitas dengan kategori baik dan $60 \%$ siswa mempunyai motivasi dan aktifitas dengan kategori baik sekali. Sedang test hasil belajar $60 \%$ siswa mempunyai nilai baik dan $40 \%$ siswa mempunyai nilai baik sekali. Hal ini disebabkan siswa sudah terbiasa dengan pembelajaran model quantum teaching. Test hasil belajar dalam bentuk ketuntasan belajar baik secara individu maupun kelas berkategori baik sekali karena mencari pengetahuan melalui motivasi dan aktifitas yang tinggi dalam pembelajaran
\end{abstract}

Kata Kunci: Quantum teaching, motivasi, aktifitas, prestasi belajar, motivator, fasilitator

\section{PENDAHULUAN}

Prestasi belajar peserta didik dipengaruhi oleh banyak faktor diantaranya berasal dari dalam (internal) dan dari luar (eksternal) (Bimo 1995 : 120-125). Faktor internal yang mempengaruhi prestasi belajar diantaranya adalah motivasi, minat, tingkat kecerdasan, dan lain-lain. Sedang faktor eksternal yang mempengaruhi prestasi belajar diantaranya adalah sarana dan prasarana, buku, metode mengajar dosen, dan lain-lain. Prestasi belajar peserta didik dapat ditingkatkan apabila faktor internal dan faktor eksternal tersebut ada dan tersedia sehingga memacu aktifitas dan kreatifitas peserta didik dalam proses belajar mengajar.

Metode atau model mengajar yang diterapkan oleh guru merupakan salah satu faktor yang mempengaruhi prestasi belajar siswa. Akan tetapi sampai saat ini masih banyak guru yang menggunakan metode atau model pembelajaran yang berpusat pada guru seperti metode ceramah. Pada metode ceramah siswa tidak mempunyai tanggung jawab apapun terhadap proses pembelajaran, peserta didik hanya membaca untuk mempersiapkan materi pelajaran yang akan dibahas, itupun kemungkinaan hanya siswa tertentu.

Sudah saatnya guru mengganti model pembelajaran yang berpusat pada siswa. Dengan pembelajaran berpusat pada siswa, siswa juga diberi beban untuk mempersiapkan dan melaksanakan proses pembelajaran. Peran guru dalam pembelajaran berpusat pada siswa adalah menyediakan lingkungan belajar yang kondusif dengan menyediakan sarana dan sumber belajar yang aktif, kreatif, menyenangkan dan memudahkan peserta didik belajar dalam mencapai tujuan pembelajaran. 
Salah satu model pembelajaran yang aktif, kreatif dan menyenangkan adalah model pembelajaran quantum teaching. Pendekatan quantum teaching adalah orkestrasi bermacammacam interaksi yang ada di dalam dan di sekitar momen belajar. Prinsip dasar dari pendekatan quantum teaching adalah "bawalah dunia mereka ke dunia kita dan hantarkan dunia kita ke dunia mereka". Maksudnya adalah selamilah dulu kehidupan siswa, kaitkan materi mata pelajaran dengan kehidupan siswa, setelah kaitan itu terbentuk bawalah dunia mereka ke dunia kita kenalkan rumusrumus, teori, persamaan yang rumit. Setelah siswa memahami dunia kita atau siswa telah memahami rumus-rumus, teori, persamaan yang rumit, hantarkan dunia kita ini untuk diaplikasikan dalam kehidupan sehari-hari siswa.

Proses belajar mengajar bukanlah menjadikan siswa yang hafal rumus, teori, persamaan, tapi bagaimana rumus, teori dan persamaan tersebut dapat digunakan untuk membantu memecahkan masalah hidupnya dan dapat diaplikasikan dalam kehidupan sehari-hari (Omar Hamalik 1995:28). Belajar melibatkan semua aspek kepribadian manusia-pikiran, perasaan, dan bahasa tubuh-disamping pengetahuan, sikap dan keyakinan sebelumnya serta persepsi masa mendatang. Dengan demikian, karena belajar berurusan dengan orang secara keseluruhan. Oleh sebab itu masuki dulu dunia mereka. Karena tindakan ini akan memberi guru ijin untuk memimpin, menuntun perjalanan peserta didik menuju kesadaran dan ilmu pengetahuan yang lebih luas. Dengan mengaitkan apa yang guru ajarkan dengan sebuah peristiwa, pikiran atau perasaan yang diperoleh dari kehidupan rumah, sosial, atletik, musik, seni, rekreasi atau akademis peserta didik.

Setelah kaitan itu terbentuk, guru dapat membawa mereka ke dunia kita, dan memberi mereka pemahaman guru mengenai isi dunia itu, setelah itu kosa kata baru, model mental, rumus, dan lain-lain dibeberkan. Seraya menjelajahi kaitan dan interaksi, baik siswa maupun guru mendapatkan pemahaman baru dan "Dunia Kita" diperluas mencakup tidak hanya para siswa, tetapi juga guru. Akhirnya, dengan pengertian yang lebih luas dan penguasaan lebih mendalam ini, siswa dapat membawa apa yang mereka pelajari ke dalam dunia mereka dan menerapkannya pada situasi baru. Bawalah Dunia Mereka ke Dunia Kita, Antarkan Dunia Kita ke Dunia Mereka. Begitulah dinamika manusia. Dan seperti itulah asas utama Quantum Teaching.

Prinsip-prinsip Quantum Teaching diantaranya: (1)Segalanya Berbicara, dari lingkungan kelas hingga bahasa tubuh, dari kertas yang dibagikan hingga rancangan pelajaran, semuanya mengirim pesan tentang belajar, (2)Segalanya bertujuan, semua yang terjadi dalam penggubahan guru mempunyai tujuan, (3)Pengalaman menggerakkan rasa ingin tahu, oleh karena itu, proses belajar paling baik terjadi ketika siswa telah mengalami informasi sebelum mereka memperoleh nama untuk apa yang mereka pelajari, (4)Akui setiap usaha, pada saat siswa mengambil langkah belajar, mereka patut mendapat pengakuan atas kecakapan dan kepercayaan diri mereka, (5)Jika layak dipelajari, maka layak pula dirayakan, perayaan adalah memberikan umpan balik mengenai kemajuan dan meningkatkan asosiasi emosi positif dengan belajar.

Langkah-langkah Belajar Quantum Teaching dikenal dengan istilah T A N D U R. yang dijabarkan sebagai berikut: (1)T:Tumbuhkan, yaitu menumbuhkan minat dengan pertanyaan "Apakah Manfaatnya Bagiku" dari manfaatkan kehidupan pelajar. (2)A:Alami, Ciptakan atau datangkan pengalaman umum yang dapat dimengerti semua siswa. (3)N: Namai, Sediakan kata kunci, konsep, model, rumus, strategi; sebuah masukan.(4)D:Domonstrasikan, sediakan kesempatan bagi siswa untuk menunjukkan bahwa mereka tahu. (5)U:Ulangi, tunjukkan siswa caracara mengulang materi dan menegaskan, "Aku tahu bahwa aku memang tahu ini". (6)R:Rayakan, pengakuan untuk penyelesaian, partisipasi dan pemerolehan ketrampilan dan ilmu pengetahuan.

Seorang guru harus dapat menjadi seorang Quantum Teacher. Bagaimana ciri-ciri seorang Quantum Teacher? Ciri-cirinya adalah: (1)Antusias: menampilkan semangat untuk hidup, (2)Berwibawa: menggerakkan orang, (3)Positif: melihat peluang dalam setiap saat, (4)Supel; mudah menjalin hubungan dengan beragam siswa, (5)Humoris: berhati lapang untuk menerima kesalahan, (6)Luwes: menemukan lebih dari satu cara untuk mencapai hasil, (7)Menerima: mencari di balik 
tindakan dan penampilan luar untuk menemukan nilai-nilai inti (8)Fasih: berkomunikasi dengan jelas, ringkas dan jujur, (9)Tulus: memiliki niat dan motivasi positif, (10)Spontan: dapat mengikuti irama dan tetap menjaga hasil, (11)Menarik dan tertarik: mengaitkan setiap informasi dengan pengalaman hidup siswa dan peduli akan diri siswa, (12)Menganggap siswa "mampu": percaya akan dan mengorkestrasi kesuksesan siswa, (13)Menetapkan dan memelihara harapan tinggi: membuat pedoman kualitas hubungan dan kualitas kerja yang memacu setiap siswa untuk berusaha sebaik mungkin.

Seorang Quantum Teacher mengorkestrasi pembelajaran sesuai dengan modalitas dan gaya para siswanya. Quantum Teacher mengajarkan kecakapan hidup di tengah-tengah kecakapan akademis, mencetak atribut mental/fisik/spiritual para siswanya. Quantum Teacher mendahulukan interaksi dalam lingkungan belajar, memperhatikan kualitas interaksi antar siswa, antara siswa dan guru dan antara siswa dan kurikulum.

Dalam menata konten, ada empat prinsip yang harus dipegang oleh guru. Keempat prinsip tersebut adalah:

a. Munculkan kesan artinya pilihlah secara sadar perkataan yang menimbulkan asosiasi positif, paculah pembelajaran dan tingkatkanlah komunikasi.

b. Arahkan fokus artinya memanfaatkan kemampuan otak yang mampu memilih dari banyaknya input indrawi, dan memusatkan perhatian otak.

c. Inklusif (bersifat mengajak) artinya sebagai seorang Quantum Teacher, guru berkeinginan menciptakan sebuah suasana kerja sama, kerja tim dan keterlibatan terutama mengingat adanya asosiasi negatif yang dimiliki beberapa siswa mengenai dinamika guru. Memilih kata secara sadar dan sengaja dapat memperkuat rasa kebersamaan dan menimbulkan asosiasi positif.

d. Spesifik (Bersifat tepat sasaran) artinya dalam menyampaikan informasi guru harus langsung masuk pada materi, tidak usah mengembangkan kata-kata atau kalimat yang menimbulkan salah tafsir.

\section{METODE PENELITIAN}

Penelitian ini dilaksanakan di SMK PGRI 3 Kota Kediri Tahun pelajaran 2019/2020. Sedangkan kelas yang dijadikan sasaran penelitian adalah kelas X-A tahun semester I. Penelitian ini menggunakan rancangan penelitian tindakan kelas (PTK) kolaboratif. Model kolaboratif ini digunakan karena peneliti memerlukan bantuan untuk melakukan observasi peserta didik pada saat proses belajar mengajar di dalam dan di luar kelas. Selain peneliti sebagai guru yang melaksanakan pembelajaran, juga melibatkan 1 orang observer, yaitu sejawat guru yang mengajar di kelas X-A semester I tahun akademik 2019/2020. Tugas observer selain sebagai patner untuk melakukan observasi juga untuk konsultasi dan berdiskusi terutama untuk membantu melakukan observasi motivasi dan aktifitas siswa pada saat proses belajar mengajar selama proses pelaksanaan penelitian.

Sedangkan model rancangan yang digunakan adalah: (1)Penyusunan rencana tindakan, meliputi: Identifikasi standart kompetensi dan kompetensi dasar, Analisis materi pembelajaran, Penyusunan perangkat persiapan mengajar, Penyusunan lembar kerja siswa, Pengadaan alat Bantu pengajaran, (2)Pelaksanaan Tindakan, (3)Pengamatan, (4)RefleksiPengumpulan data dilakukan menggunakan 2 macam instrumen, yaitu: (1)Lembar observasi untuk melihat motivasi dan aktifitas siswa selama proses belajar mengajar dengan pendekatan quantum teaching. (2)Soal-soal tes hasil belajar untuk mengukur prestasi belajar siswa setelah pembelajaran quantum teaching berakhir. 
Sumber datanya untuk mengukur motivasi dan aktifitas siswa saat pembelajaran quantum teaching berlangsung adalah siswa kelas X-A semester I Tahun pelajaran 2019/2020 sebanyak 35 siswa. Tehnik pelaksanaan pengumpulan data untuk melihat motivasi dan aktifitas pembelajaran quantum teaching dengan melakukan observasi pada saat proses belajar mengajar satu kompetensi dasar yaitu menyusun laporan keuangan perusahaan dagang. Satu kompetensi dasar ini akan dilaksanakan dalam 3 pertemuan atau 3 siklus yaitu siklus pertama jurnal umum, siklus kedua jurnal penyesuaian, neraca lajur dan laporan keuangan dan siklus ketiga jurnal penutup dan jurnal balik. Sedangkan untuk melihat prestasi belajar dilakukan dengan melakukan tes pada akhir setiap siklus. Berikut ini kisi-kisi lembar observasi motivasi dan aktifitas pembelajaran quantum teaching.

Tabel 3.1 Kisi-kisi lembar observasi motivasi dan aktivitas pembelajaran quantum teaching

\begin{tabular}{llll}
\hline No. & INDIKATOR & SKOR & \\
\hline 1. & Tumbuhkan & \\
\hline 2. & Alami & \\
\hline 3. & Namai & \\
\hline 4. & Demontrasikan & \\
\hline 5. & Ulangi & \\
\hline 6. & Rayakan &
\end{tabular}

Cara scoring indikator motivasi dan aktivitas pembelajaran quantum teaching adalah:

1. Memberikan skor $1=$ motivasi dan aktivitas PBM kurang sekali

2. Memberikan skor 2 = motivasi dan aktivitas PBM kurang

3. Memberikan skor $3=$ motivasi dan aktivitas PBM cukup

4. Memberikan skor $4=$ motivasi dan aktivitas PBM baik

5. Memberikan skor $5=$ motivasi dan aktivitas PBM baik sekali

6. Menjumlahkan masing-masing skor tersebut di kolom jumlah, dimana jumlah terendah 6 dan jumlah tertinggi 30 .

Sedangkan untuk melihat prestasi belajar setelah pembelajaran quantum teaching dilakukan dengan melakukan test setelah pembelajaran quantum teaching berakhir yaitu di akhir setiap siklus. Test hasil belajar ini dimaksudkan untuk memperoleh gambaran mengenai hasil belajar siswa setelah pembelajaran quatum teaching berakhir. Bentuk testnya adalah pilihan ganda dan tugas terstruktur.

Cara pemberian skor pada test di setiap akhir siklus adalah berpedoman pada bobot masing-masing jenis soal. Untuk jenis pilihan ganda bobot soalnya adalah 20 dengan skor masingmasing soal 1 dengan jumlah soal 20 . Untuk jenis tugas terstuktur bobot soalnya adalah 50 dengan skor totalmya 50 dengan jumlah soal 1 , total skor dari kedua jenis soal tersebut adalah 70 . Jumlah skor motivasi dan aktifitas peserta didik ditambah dengan nilai hasil test jumlahnya 100.

Data hasil observasi motivasi dan aktifitas siswa selama mengikuti proses belajar mengajar dengan pendekatan quantum teaching dan nilai hasil test akan dianalisis bersama-sama guna menentukan apakah pembelajaran quantum teaching dapat meningkatkan prestasi belajar siswa. Selanjutnya berdasar data-data yang terkumpul setelah dilakukan tabulasi dan scoring, akan ditafsirkan menggunakan kajian teori yang telah dikembangkan, serta menggunakan pengalaman empiris yang sering diamati peneliti dalam kehidupan sehari-hari siswa.

Kriteria dan refleksi data-data motivasi dan aktifitas pembelajaran quatum teaching akan digunakan kriteria yaitu:

1. Skor $6-10=$ (kurang sekali) artinya siswa kurang sekali ada motivasi dan aktifitas PBM

2. Skor $11-15=$ (kurang) artinya siswa kurang ada motivasi dan aktifitas PBM

3. Skor $16-20$ (cukup) artinya motivasi dan aktifitas PBM siswa cukup

4. Skor 21 - 25 (baik) artinya motivasi dan aktifitas PBM siswa baik

5. Skor $26-30$ (baik sekali) artinya motivasi dan aktifitas PBM siswa baik sekali 
Untuk ketuntasan individual adalah diatas 51 taraf penguasaan materi, dan Untuk ketuntasan kelompok (kelas) adalah $85 \%$ dari jumlah siswa telah mencapai 51 taraf penguasaan materi yang diberikan. Sedangkan data test untuk setiap akhir siklus setelah dilakukan koreksi dan scoring akan dianalisis berdasarkan kriteria ketuntasan belajar (mastery learning), yaitu:

1. Untuk hasil test 0 - 30 Prestasi belajar sangat kurang

2. Untuk hasil test 31 - 40 Prestasi belajar kurang

3. Untuk hasil test 41 - 50 Prestasi belajar cukup

4. Untuk hasil test 51 - 60 Prestasi belajar baik

5. Untuk hasil test $61-70$ Prestasi belajar baik sekali.

\section{PEMBAHASAN}

\section{Persiapan}

Sebelum melakukan penelitian, peneliti membuat persiapan sebagai berikut:

a. Memberitahukan rencana penelitian tindakan kelas kepada kepala sekolah, sekaligus untuk memperoleh saran dan masukan yang mungkin berguna saat pelaksanaan.

b. Meminta persetujuan salah seorang rekan guru, sekaligus meminta kesediaan untuk berdiskusi dan membantu pelaksanaan penelitian sebagai kolaborator (observer).

c. Penyusunan perangkat persiapan pembelajaran yang terdiri dari: Identifikasi standart kompetensi dan kompetensi dasar, Analisis materi pembelajaran, Penyusunan perangkat persiapan mengajar, Penyusunan lembar kerja siswa, Pengadaan alat Bantu pengajaran.

d. Membuat instrumen-instrumen yang digunakan, yaitu: lembar observasi motivasi dan aktifitas proses belajar mengajar dengan pendekatan pembelajaran quantum teaching, lembar soal test yang digunakan diakhir setiap siklus, Mempersiapkan beberapa lembar daftar absensi dan daftar nilai yang akan dijadikan sasaran penelitian.

2. Siklus pertama. Pelaksanaan Pembelajaran quantum teaching dengan indikator jurnal umum. meliputi 4 tahapan yang akan dilalui sebagai berikut:

a. Persiapan (planning): Identifikasi standart kompetensi dan kompetensi dasar menyusun laporan keuangan perusahaan dagang dengan indikator jurnal umum, Analisis materi pembelajaran, Penyusunan Rencana Pembelajaran (lihat di lampiran), Penyusunan lembar kerja siswa berupa soal-soal test (lihat di lampiran), Pengadaan media atau alat Bantu pengajaran berupa gambar/skema siklus akuntansi perusahaan dagang (lihat di buku kegiatan siswa

b. Pelaksanaan (Acting)

Sesuai dengan model pembelajaran quantum teaching, guru tidak langsung menjelaskan tapi menyampaikan materi kuliah sesuai dengn model quantum teaching yaitu:

- Tumbuhkan. Dalam hal ini guru menumbuhkan minat siswa untuk belajar yaitu dengan menerangkan manfaat mempelajari jurnal umum perusahaan dagang.

- Alami. Datangkan pengalaman siswa untuk membahas suatu materi pelajaran agar tersambung antara pengalaman siswa dengan suatu materi pelajaran. Misalnya dengan menerangkan aktifitas perusahaan dagang yang utama adalah menjual dan membeli barang dagangan

- Namai. Berikan kata-kata kunci untuk memudahkan mahasiswa untuk memahami materi tersebut

- Demonstrasikan. Lihatkan siswa dengan gambar/skema yang dapat dilihat sehingga menarik perhatian dan dapat meningkatkan pemahaman terhadap materi tersebut.

- Ulangi. Ulangi materi-materi yang penting yang perlu digaris bawahi oleh siswa dengan memberi penegasan, boleh dari guru atau dari siswa. 
- Rayakan. Setiap keberhasilan siswa misalnya siswa dapat menjawab pertanyaan guru, dapat menjurnal, dapat membetulkan apabila ada jawaban yang salah berilah penghargaan sebagai bentuk keberhasilan.

c. Observasi. Guru observer melakukan pengamatan pada motivasi dan aktifitas siswa pada saat proses belajar mengajar di kelas. Observasi ini untuk mengetahui apakah proses pembelajaran quantum teaching dapat meningkatkan motivasi dan aktifitas belajar anak ( T A N D U R ) karena pembelajaran dilaksanakan yang aktif, kreatif dan menyenangkan. Berikut ini disajikan hasil observasi motivasi dan aktifitas siswa dalam PBM model quantum teaching.

Tabel 4.1: Hasil observasi motivasi dan aktifitas siswa dalam PBM model quantum teaching siklus pertama.

\begin{tabular}{llccccccc}
\hline No & Nama & \multicolumn{6}{c}{ Indikator } & \multicolumn{2}{c}{ Total } \\
\cline { 3 - 8 } & & Tumbuhkan & Alami & Namai & Demonstrasi & Ulangi & Rayakan & \\
\hline 1 & Afrilia & 2 & 2 & 3 & 3 & 3 & 2 & 15 \\
\hline 2 & Yuli P & 3 & 3 & 3 & 3 & 2 & 3 & 17 \\
\hline 3 & Rizki R & 3 & 2 & 2 & 2 & 3 & 2 & 14 \\
\hline 4 & Sriyani & 2 & 2 & 4 & 3 & 2 & 3 & 16 \\
\hline 5 & Novan & 2 & 3 & 2 & 2 & 2 & 2 & 13 \\
\hline
\end{tabular}

Dari hasil analisa data observasi motivasi dan aktifitas belajar dengan menggunakan pendekatan quantum teaching siklus pertama dari kelima sampel penelitian menunjukkan tiga siswa mempunyai skor antara 11 - 15 sehingga $60 \%$, pembelajaran quantum teaching siklus pertama kurang meningkatkan motivasi dan aktifitas belajar dalam arti belum mencapai (T A N D U R). Dua siswa mempunyai skor antara 16 - 20 sehingga $40 \%$ pembelajaran quantum teaching siklus pertama cukup meningkatkan motivasi dan aktifitas belajar (T A N D U R).

Tabel 4.2 Nilai test materi pelajaran siklus pertama

\begin{tabular}{clccc}
\hline No. & Nama Siswa & Nilai Test Pilihan Ganda & Nilai Test Uraian & Jumlah \\
\hline 1. & Afrilia & 12 & 35 & 47 \\
\hline 2. & Yuli P & 8 & 25 & 33 \\
\hline 3. & Rizka R & 16 & 30 & 46 \\
\hline 4. & Sriyani & 12 & 35 & 47 \\
\hline 5. & Novan & 4 & 30 & 34 \\
\hline
\end{tabular}

Dari hasil siklus pertama dihasilkan data sebagai berikut: Ada 2 siswa yang memperoleh nilai antara 31 - 40 sehingga $40 \%$ siswa berkategori mempunyai nilai kurang. Ada 3 siswa yang memperoleh nilai antara 41 - 50 sehingga $60 \%$ siswa berkategori mempunyai nilai cukup. Dilihat dari ketuntasan proses belajar mengajar secara individu belum ada siswa yang mempunyai nilai diatas 51 maka belum tuntas dalam memahami materi pelajaran. Dilihat dari ketuntasan kelas karena semua siswa juga belum ada yang mempunyai nilai diatas 51 , maka secara keseluruhan kelas belum menampakkan ketuntasan belajar.

\section{d. Refleksi Siklus 1}

Berdasarkan data observasi dan aktifitas belajar quantum teaching siklus pertama dihasilkan kesimpulan bahwa motivasi dan aktifitas belajar siswa berkategori kurang (60\%) dan berkategori cukup (40\%) apabila dilihat dari (T A N D U R). Sedang dilihat dari hasil test materi pelajaran dihasilkan kesimpulan $40 \%$ siswa mempunyai nilai yang kurang dan $60 \%$ siswa mempunyai nilai yang cukup. Baik secara individu maupun kelas belum menampakkan ketuntasan belajar. Hal tersebut dikarenakan siswa belum terbiasa menggunakan pembelajaran quantum teaching. Siswa selama ini terbiasa dengan metode ceramah yang tidak menuntut keterlibatan siswa yang tinggi dalam pembelajaran. 


\section{Siklus kedua.}

Pelaksanaan Pembelajaran quantum teaching dengan indikator jurnal penyesuaian dan neraca lajur meliputi 4 tahapan yang akan dilalui sebagai berikut:

a. Persiapan (planning): Identifikasi standart kompetensi, kompetensi dasar dan analisis materi pelajaran: menyusun laporan keuangan perusahaan dagang dengan indikator menyusun jurnal penyesuaian dan neraca lajur, Penyusunan Rencana Pembelajaran (lihat di lampiran), Penyusunan lembar kerja siswa berupa soal-soal test (lihat di lampiran), Pengadaan media atau alat Bantu pengajaran berupa gambar/skema jurnal penyesuaian dan neraca lajur. (lihat di buku kegiatan siswa)

b. Pelaksanaan (Acting) menyampaikan materi menjelaskan tapi menyampaikan materi sesuai dengan model quantum teaching yaitu:

- Tumbuhkan. Dalam hal ini guru menumbuhkan minat siswa untuk belajar yaitu dengan menerangkan manfaat mempelajari jurnal penyesuaian dan neraca lajur.

- Alami. Datangkan pengalaman siswa untuk membahas suatu materi pelajaran agar tersambung antara pengalaman siswa dengan suatu materi pelajaran.

- Namai. Berikan kata-kata kunci untuk memudahkan siswa untuk memahami materi pelajaran tersebut seperti

- Demonstrasikan. Lihatkan siswa dengan gambar/skema jurnal penyesuaian dan neraca lajur. Tunjukkan satu persatu proses menjurnal dan memasukkan kedalam neraca lajur.

- Ulangi. Ulangi materi-materi yang penting yang perlu digaris bawahi oleh siswa dengan memberi pemguatan, boleh dari guru atau dari siswa. Dalam tahap ini guru membimbing siswa menarik benang merah/kesimpulan

- Rayakan. Setiap keberhasilan siswa misalnya siswa dapat menjawab pertanyaan, mengerjakan soal, memperbaiki jawaban yang salah, siswa dapat menyimpulkan, berilah penghargaan sebagai bentuk keberhasilan. Pengamatan (Observing)

c. Guru observer melakukan pengamatan pada motivasi dan aktifitas siswa pada saat proses belajar mengajar di kelas. Observasi ini untuk mengetahui apakah proses pembelajaran quantum teaching dapat meningkatkan motivasi dan aktifitas belajar peserta didik ( T A N D U R ) karena pembelajaran dilaksanakan yang aktif, kreatif dan menyenangkan. Setelah siklus kedua selesai akan diadakan test/ujian yaitu untuk melihat apakah pembelajaran quantum teaching akan dapat meningkatkan prestasi belajar siswa. Berikut hasil observasi motivasi dan aktifitas siswa dalam PBM model quantum teaching.

Tabel 4.3: Hasil observasi motivasi dan aktifitas siswa dalam PBM quatum teaching siklus kedua.

\begin{tabular}{llccccccc}
\hline No & Nama & \multicolumn{9}{c}{ Indikator } & Total \\
\cline { 3 - 8 } & & Tumbuhkan & Alami & Namai & Demonstrasi & Ulangi & Rayakan & \\
\hline 1 & Afrilia & 3 & 4 & 4 & 3 & 3 & 2 & 19 \\
\hline 2 & Yuli P & 4 & 4 & 3 & 3 & 2 & 2 & 18 \\
\hline 3 & Rizki R & 5 & 4 & 3 & 3 & 3 & 3 & 21 \\
\hline 4 & Sriyani & 4 & 5 & 5 & 3 & 2 & 3 & 27 \\
\hline 5 & Novan & 4 & 4 & 5 & 5 & 3 & 2 & 13 \\
\hline
\end{tabular}

Dari hasil analisa data observasi motivasi dan aktifitas belajar dengan menggunakan metode quantum teaching siklus kedua dari kelima sampel penelitian menunjukkan dua siswa mempunyai skor antara 16 - 20 sehingga $40 \%$, pembelajaran quantum teaching cukup meningkatkan motivasi dan aktifitas belajar d (T A N D U R). Tiga siswa mempunyai skor antara 21-25 sehingga $60 \%$, pembelajaran quantum teaching siklus kedua baik dalam meningkatkan motivasi dan aktifitas belajar (T A N D U R). 
Tabel 4.4 Nilai test materi pelajaran siklus kedua

\begin{tabular}{|c|l|c|c|c|}
\hline No. & Nama Siswa & Nilai Test Pilihan Ganda & Nilai Test Uraian & Jumlah \\
\hline 1. & Afrilia & 12 & 35 & 47 \\
\hline 2. & Yuli P & 16 & 40 & 56 \\
\hline 3. & Rizka R & 16 & 30 & 46 \\
\hline 4. & Sriyani & 12 & 40 & 52 \\
\hline 5. & Novan & 8 & 45 & 53 \\
\hline
\end{tabular}

Dari hasil analisa data test materi pelajaran model quantum teaching siklus kedua dihasilkan data sebagai berikut: Ada 2 mahasiswa yang memperoleh nilai antara 41 - 50 sehingga $40 \%$ siswa berkategori mempunyai nilai cukup. Ada 3 siswa yang memperoleh nilai antara $51-60$ sehingga $60 \%$ siswa berkategori mempunyai nilai baik. Dilihat dari ketuntasan proses belajar mengajar secara individu $60 \%$ siswa sudah tuntas dalam memahami materi pelajaran. Tapi dilihat dari ketuntasan kelas karena masih $60 \%$ siswa yang mempunyai nilai diatas 51 belum $85 \%$, maka secara keseluruhan kelas belum menampakkan ketuntasan belajar.

\section{d. Refleksi Siklus 2}

Berdasarkan data observasi dan aktifitas belajar siklus kedua dihasilkan kesimpulan bahwa motivasi dan aktifitas belajar siswa berkategori cukup (40\%) dan berkategori baik (60\%), apabila dilihat dari (T A N D U R). Sedang dilihat dari hasil test materi pelajaran secara individu $40 \%$ siswa berkategori cukup dan $60 \%$ siswa berkategori baik. Dilihat dari tingkat ketuntasan belajar ternyata secara individu $60 \%$ siswa sudah tuntas belajarnya dan apabila dilihat dari ketuntasan kelas ternyata belum menampakkan ketuntasan belajar. Hal ini terjadi sebab: siswa sudah ada peningkatan, Siswa sudah mulai terbiasa dengan model pembelajaran quantum teaching dan guru sangat mengurangi dominasinya dalam pembelajaran

\section{Siklus ketiga}

Pelaksanaan Pembelajaran quantum teaching dengan indikator jurnal penutup dan jurnal balik meliputi 4 tahapan yang akan dilalui sebagai berikut:

a. Persiapan (planning): Identifikasi standart kompetensi, kompetensi dasar dan analisis materi pembelajaran menyusun laporan keuangan perusahaan dagang dengan indikator jurnal penutup dan jurnal balik, penyusunan Rencana Pembelajaran (lihat di lampiran), Penyusunan lembar kerja siswa berupa soal-soal test (lihat di lampiran). Pengadaan media atau alat Bantu pengajaran berupa gambar/skema jurnal penutup dan jurnal balik (lihat di buku kegiatan siswa)

b. Pelaksanaan (Acting). Setelah membuka pelajaran guru masuk pada kegiatan inti yaitu menyampaikan materi pelajaran. Seperti telah disampaikan di atas indikator dari materi ini adalah siswa dapat menyusun jurnal penutup dan jurnal balik. Guru menjelaskan materi sesuai dengan model pembelajaran quantum teaching, yaitu:

- Tumbuhkan. Dalam hal ini guru menumbuhkan minat siswa untuk belajar yaitu dengan menerangkan manfaat mempelajari jurnal penutup dan jurnal balik. Tujuan dari jurnal balik ini adalah menjaga jumlah rekening agar sesuai dengan keadaan yang sebenarnya. Jadi dengan mempelajari jurnal penutup dan jurnal balik kita akan tahu jumlah kenaikan dan penurunan modal dan saldo rekening menunjukkan saldo yang sebenarnya.

- Alami. Datangkan pengalaman siswa untuk membahas suatu materi pelajaran agar tersambung antara pengalaman siswa dengan suatu materi pelajaran.

- Namai. Berikan kata-kata kunci untuk memudahkan siswa untuk memahami materi tersebut seperti, saudara sekalian apabila kita mau membuat jurnal penutup pada perusahaan dagang pertama-tama ingat pindahkan rekening yang dulu kredit sekarang didebet. Sebaliknya rekening yang dulu debet sekarang di kredit.. 
- Demonstrasikan. Lihatkan siswa dengan gambar/skema jurnal penutup dan jurnal pembalik. Tunjukkan satu persatu proses membuat jurnal penutup dan jurnal pembalik. Dengan adanya gambar/skema yang dapat menarik perhatian siswa dapat digunakan untuk meningkatkan motivasi belajarnya.

- Ulangi. Ulangi materi-materi yang penting yang perlu digaris bawahi oleh siswa dengan memberi penegasan, boleh dari guru atau dari siswa.

- Rayakan. Setiap keberhasilan siswa misalnya siswa dapat menjawab pertanyaan, dapat mengerjakan soal, dapat mengoreksi jawaban yang salah, berilah penghargaan sebagai bentuk keberhasilan.

\section{c. Observasi Siklus 3.}

Guru observer melakukan pengamatan motivasi dan aktifitas siswa untuk mengetahui apakah proses pembelajaran quantum teaching dapat meningkatkan motivasi dan aktifitas belajar peserta didik. Berikut ini disajikan hasil observasi motivasi dan aktifitas siswa dalam PBM model quantum teaching siklus ketiga.

Tabel 4.5: Hasil observasi motivasi dan aktifitas siswa dalam PBM model quantum teaching siklus ketiga

\begin{tabular}{llccccccc}
\hline No & Nama & \multicolumn{9}{c}{ Indikator } & \multicolumn{2}{c}{ Total } \\
\cline { 3 - 8 } & & Tumbuhkan & Alami & Namai & Demonstrasi & Ulangi & Rayakan & \\
\hline 1 & Afrilia & 5 & 4 & 5 & 4 & 5 & 4 & 27 \\
\hline 2 & Yuli P & 4 & 4 & 4 & 5 & 3 & 2 & 24 \\
\hline 3 & Rizki R & 5 & 4 & 5 & 5 & 4 & 3 & 26 \\
\hline 4 & Sriyani & 5 & 5 & 5 & 5 & 4 & 4 & 28 \\
\hline 5 & Novan & 4 & 5 & 5 & 3 & 4 & 4 & 25 \\
\hline
\end{tabular}

Dari hasil analisa data observasi motivasi dan aktifitas belajar pada siklus ketiga menunjukkan dua siswa mempunyai skor antara 21 - 25 sehingga $40 \%$, pembelajaran siklus ketiga mempunyai kategori baik meningkatkan motivasi dan aktifitas belajar. Tiga siswa mempunyai skor antara 26 - 30 sehingga $60 \%$, pembelajaran quantum teaching siklus ketiga sudah baik sekali

Tabel 4.6 Nilai test materi pelajaran siklus ketiga

\begin{tabular}{clccc}
\hline No. & Nama Siswa & Nilai Test Pilihan Ganda & Nilai Test Uraian & Jumlah \\
\hline 1. & Afrilia & 16 & 40 & 56 \\
\hline 2. & Yuli P & 20 & 45 & 65 \\
\hline 3. & Rizka R & 16 & 50 & 66 \\
\hline 4. & Sriyani & 12 & 40 & 52 \\
\hline 5. & Novan & 12 & 45 & 57 \\
\hline
\end{tabular}

Dari hasil analisa data hasil test materi pelajaran siklus ketiga dihasilkan data sebagai berikut: Ada 3 siswa yang memperoleh nilai antara 51 - 60 sehingga $60 \%$ siswa berkategori mempunyai nilai baik.. Ada 2 siswa yang memperoleh nilai antara $61-70$ sehingga $40 \%$ siswa berkategori mempunyai nilai baik sekali. Dilihat dari ketuntasan proses belajar mengajar secara individu $100 \%$ siswa sudah tuntas dalam memahami materi pelajaran. Sedang dilihat dari ketuntasan kelas karena $100 \%$ siswa sudah mempunyai nilai diatas 51 , maka secara keseluruhan kelas sudah menampakkan ketuntasan belajar.

d. Refleksi Siklus ketiga

Dari siklus ketiga dihasilkan kesimpulan bahwa motivasi dan aktifitas belajar siswa berkategori baik $(40 \%)$ dan berkategori baik sekali $(60 \%)$. Sedang dilihat dari hasil test materi pelajaran secara individu $60 \%$ siswa berkategori baik dan $40 \%$ siswa berkategori baik sekali. Dilihat dari tingkat ketuntasan belajar ternyata secara individu $100 \%$ siswa sudah tuntas belajarnya dan apabila dilihat dari ketuntasan kelas ternyata juga sudah menampakkan ketuntasan belajar. Hal ini bisa terjadi sebab: siswa sudah terbiasa dengan model pembelajaran quantum teaching 
artinya dengan guru melakukan kebiasaan model pembelajaran yang dapat meningkatkan motivasi dan aktifitas, siswa lama kelamaan juga akan mengikuti dan membiasakan diri untuk beradaptasi dengan model pembelajaran yang diterapkan oleh guru. Hasil test menunjukkan nilai dengan kategori baik dan baik sekali karena dengan motivasi dan aktifitas yang tinggi dalam pembelajaran siswa merasa bertanggung jawab untuk mencari pengetahuan.

Hal ini juga menunjukkan bahwa guru telah menjalankan fungsinya dengan baik, sebagai motivator dan fasilitator apabila ada peserta didik yang mengalami kesulitan dalam belajar. Berikut ini adalah rekapitulasi motivasi belajar dan hasil belajar siklus 1, siklus 2 dan siklus 3 dalam bentuk diagram

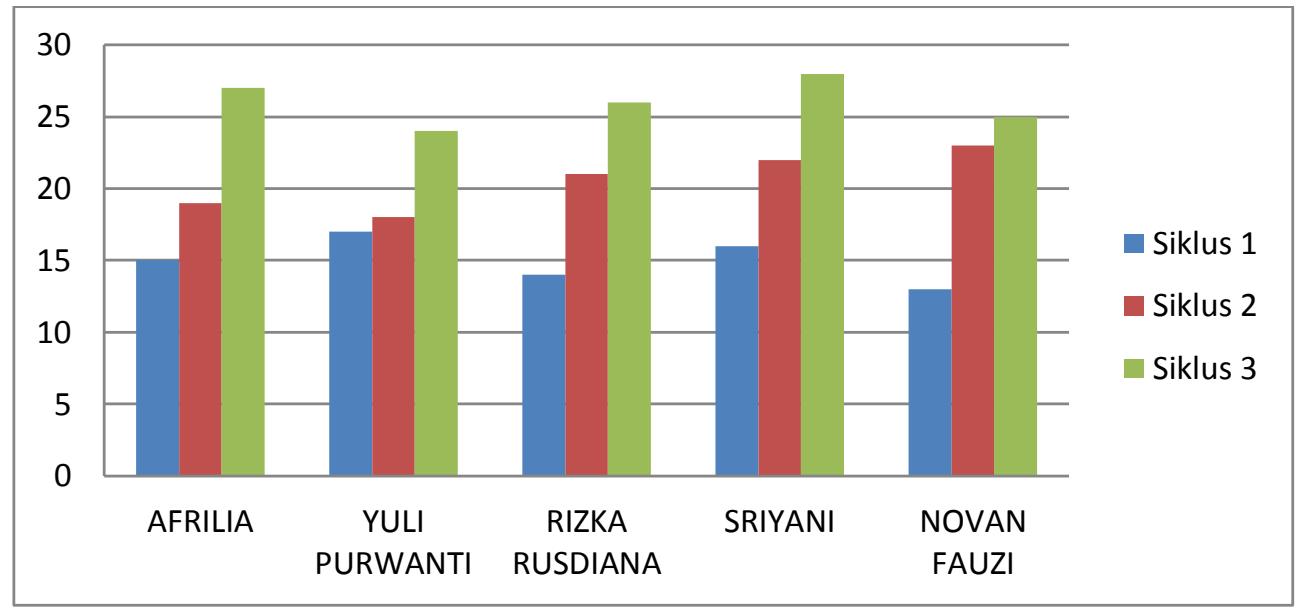

Gambar 1: Peningkatan Motivasi belajar siklus 1, siklus 2 dan siklus 3

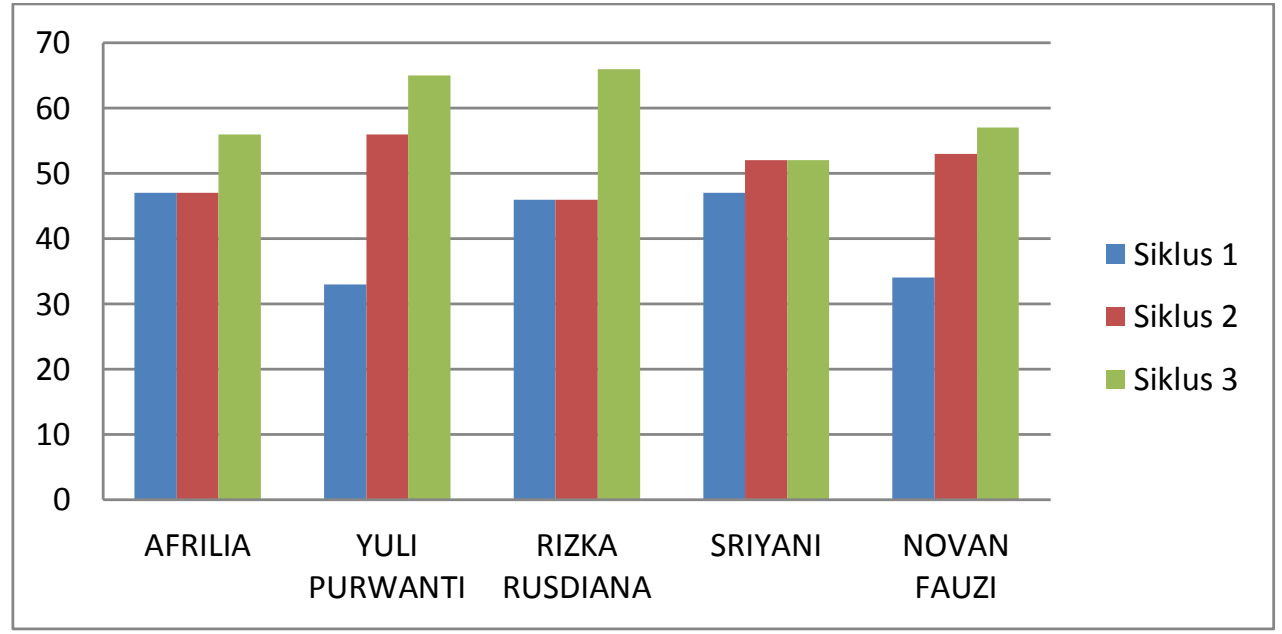

Gambar 2: Peningkatan Hasil belajar siklus 1, siklus 2 dan siklus 3

\section{SIMPULAN}

1. Pelaksanaan pembelajaran model quantum teaching siklus pertama masih menghasilkan motivasi dan aktifitas peserta dengan kategori $60 \%$ kurang dan $40 \%$ cukup. Sedang test hasil belajar menunjukkan nilai $40 \%$ kurang dan $60 \%$ cukup. Hal ini disebabkan peserta didik belum terbiasa dengan pembelajaran model quantum teaching. Peserta didik masih terbiasa dengan metode ceramah yang hanya menerima informasi dari guru. Tugas guru adalah melanjutkan model pembelajaran quantum teaching dengan diberi tambahan metode ceramah agar peserta didik dapat memahami atas materi pelajaran yang diberikan (diberikan pada siklus kedua). 
2. Pelaksanaan pembelajaran dengan model quantum teaching ditambah dengan metode ceramah dimana guru masih menjelaskan hal-hal yang penting menghasilkan motivasi dan aktifitas siswa $40 \%$ berkategori cukup dan $60 \%$ berkategori baik. Sedang test hasil belajar menunjukkan $40 \%$ siswa mempunyai nilai cukup dan $60 \%$ siswa mempunyai nilai baik. Apabila dibandingkan dengan siklus pertama motivasi, aktifitas dan hasil belajar siklus kedua mengalami kenaikan karena siswa sudah mulai beradaptasi dengan pembelajaran quantum teaching sehingga motivasi dan aktifitas belajarnya meningkat. Disamping itu test hasil belajar juga meningkat karena pengetahuan didapat dari dua sumber yaitu dari aktifitas siswa dan dari informasi dari guru lewat metode ceramah. Namun demikian untuk siklus berikutnya guru harus mengurangi dominasi dalam pembelajaran. Guru hanya sebagai motivator dan fasilitator apabila ada peserta didik yang mengalami kesulitan belajar. Sehingga dalam pembelajaran siklus ketiga guru secara murni melaksanakan pembelajaran model quantum teaching.

3. Pembelajaran model quantum teaching siklus ketiga menunjukkan $40 \%$ siswa mempunyai motivasi dan aktifitas dengan kategori baik dan $60 \%$ siswa mempunyai motivasi dan aktifitas dengan kategori baik sekali. Sedang test hasil belajar menunjukkan $60 \%$ siswa mempunyai nilai baik dan $40 \%$ siswa mempunyai nilai baik sekali. Hal ini disebabkan siswa sudah terbiasa dengan pembelajaran model quantum teaching. Demikian pula test hasil belajarnya menunjukkan ketuntasan belajar baik secara individu maupun kelas karena baik secara individu maupun bersama-sama berusaha mencari pengetahuan melalui motivasi dan aktifitas yang tinggi dalam pembelajaran.

4. Hipotesis telah dibuktikan bahwa salah satu upaya meningkatkan motivasi, aktifitas dan hasil belajar dengan menerapkan model pembelajaran quantum teaching.

\section{SARAN PENGEMBANGAN PENELITIAN LANJUT}

1. Dalam menerapkan pembelajaran quantum teaching hendaknya guru menganalisis materi pelajaran disesuaikan dengan strategi belajar mengajar model quantum teaching yaitu T A ND U R. Dengan demikian guru memerlukan persiapan yang matang baik untuk menyusun perangkat pembelajaran maupun aktifitas pembelajaran.

2. Dalam pembelajaran quantum teaching hendaknya siswa mempunyai kesadaran yang tinggi untuk terlibat dalam proses pembelajaran karena pengetahuan dapat ditemukan melalui motivasi dan aktifitas yang tinggi dalam proses belajar mengajar.

\section{DAFTAR RUJUKAN}

F. Fatty kasmiran Woeryo 1982, Pengantar Psikologi Umum. Surabaya. Usaha Nasional.

H. Abu, 1986. Tehnik Belajar Yang Tepat. Semarang. Yudistira.

Hadari Nawawi, 1985. Metodologi Riset. Balai Percetakan Fakultas Ekonomi Universitas Gajah Mada.

Nana Sudjana, 1988. Metode Penelitian Pendidikan. Yogjakarta. Balai Percetakan Fakultas Ekonomi Universitas Gajah mada.

Robert N Gagne 1987, Belajar dan Pembelajaran. Bandung. Tarsito.

Suharsini Arikunto 1986, Prosedur Penelitian suatu pendekata praktek, Jakarta PT. Bina Aksara.

Umar Hamalik, 1980, Pengantar Interaksi Belajar Mengajar Dasar. Bandung. Tarsito.

Winarno Surahmad 1979. Metode Pengajaran Nasional. Bandung IKIP Bandung .

Wasis, 1977. Ilmu Ekonomi. Bandung. Tarsito.

Wayan Ardana 1982, Metodologi Penelitian. Badan Penerbitan IKIP Malang. 